\title{
The prevalence rates of major chronic diseases in retired and in-service Chinese military officers (2000-2016): a meta-analysis
}

Thermite Mara ${ }^{\dagger}$, Long-Teng Ma ${ }^{\dagger}$, Shuo Wang ${ }^{\dagger}$, Ling Wang, Fan Yang, Jia-Hui Song, Yi-Chun Cao, Jian-Hua Yin and Guang-Wen Cao*

\begin{abstract}
Background: Chronic diseases cause a tremendous burden to the military medical system. However, the prevalence rates of major chronic diseases among military officers remain unclear in China.

Methods: China National Knowledge Infrastructure (CNKI), Wanfang Database, VIP Database for Chinese Technical Periodicals (VIP), PubMed and Web of Science were searched for studies (from 2000 to 2016) concerning 6 major chronic diseases: hypertension, hyperlipidemia, diabetes mellitus, heart diseases, cerebrovascular diseases, and chronic obstructive pulmonary diseases (COPD) in Chinese military officers following strict inclusion and exclusion criteria. Three researchers independently extracted data from the included studies, and a fourth researcher reviewed and solved every disagreement. Statistical analysis was performed with STATA 14.0 and R 3.3.2. Heterogeneity was evaluated by the $P^{2}$ value. A random effect model was performed to combine the heterogeneous data. The Egger test was performed to test the publication bias.

Results: A total of 90,758 military officers derived from 75 articles were pooled together. Publication bias was only observed in 37 studies reporting heart disease $\left(P_{\text {Egger test }}=0.01\right)$. The overall prevalence rates of hypertension, hyperlipidemia, diabetes mellitus, heart diseases, cerebrovascular diseases, and COPD were $46.6 \%$ (95\% Cl 41.8-51.5\%), $30.9 \%$ (26.4-35.7\%), 20.7\% (16.5-25.7\%), 48.2\% (41.7-54.9\%), 20.2\% (14.8-26.9\%) and 16.6\% (12.9-21.0\%), respectively. The prevalence rates of hypertension, diabetes, heart disease, cerebrovascular disease, and COPD, rather than hyperlipidemia, increased with age in Chinese military officers. Heart diseases $\left(P_{Q \text {-test }}<0.001\right)$ and hypertension $\left(P_{\text {Q-test }}<0.001\right)$ increased sharply in retired officers compared with officers in service. Cerebrovascular disease was more frequent in Northern Theater Command than in any other theater command $\left(P_{\text {Q-test }}<0.001\right)$.

Conclusions: Major chronic diseases heavily affect Chinese military officers, especially retirees. Medical intervention should be enforced on the prevention of cerebrovascular diseases in those working in cold areas in the north, as well as hypertension and heart diseases in retirees.
\end{abstract}

Keywords: Chronic diseases, Meta-analysis, Hypertension, Hyperlipidemia, Diabetes, Cerebrovascular disease, Chronic obstructive pulmonary disease

\footnotetext{
*Correspondence: gcao@smmu.edu.cn

${ }^{\dagger}$ Equal contributors

Department of Epidemiology, Second Military Medical University, Shanghai 200433, China
} 


\section{Background}

With the development of medical services in China, group 1 (communicable, maternal, perinatal, and nutritional conditions) and group 3 (injury) diseases have decreased remarkably, and group 2 diseases (non-communicable chronic diseases) have gradually increased (group 1, 2 and 3 are standard classification of diseases for ICD-10) [1]. Chronic diseases, which are characterized by high prevalence, long time course, and refraction to treatment, place a tremendous burden on the medical service systems of China.

The prevalence rates of major chronic diseases among civilians on the national level have been investigated and reported, while the prevalence rates of chronic diseases among whole military officers remain unclear [2-4]. Many previous small-scale epidemiological studies on the prevalence of chronic diseases in military officers have been performed since the 1960s. However, the results of these small-scale studies are poorly generalizable, because their target population is from different age groups or different theater commands. To obtain a representative estimate of the prevalence rates of chronic diseases among most Chinese military officers, we performed this meta-analysis.

In this study, we searched literature databases for studies concerning chronic disease prevalence rates in Chinese military officers. We focused on six major chronic diseases, including hypertension, hyperlipidemia, diabetes mellitus, heart diseases, cerebrovascular diseases, and chronic obstructive pulmonary disease (COPD). We conducted subgroup analyses between retired officers and those in service, among different age groups, and among the 5 theater commands.

\section{Methods}

\section{Search strategy}

Three authors searched the following databases independently: China National Knowledge Infrastructure (CNKI), Wanfang Database, VIP Database for Chinese Technical Periodicals (VIP), PubMed and Web of Science. The following search items and their synonyms were used: "Hypertension", "Hyperlipidemia", "Diabetes Mellitus", "Heart Diseases", "Cerebrovascular Diseases", "Chronic Pulmonary Obstructive Diseases", "China Military", and "China Military Retirement". Relevant literature was found in CNKI, Wanfang and VIP but not in PubMed and Web of Science.

\section{Inclusion and exclusion criteria}

The inclusion criteria were as follows: 1) the study population included in-service or retired Chinese military officers; 2) the study design was longitudinal or cross-sectional; 3) the study population and the number of patients with each disease was clearly described; 4) the studies showed the age groups of the study population; 5) the diseases were diagnosed according to the national criteria (National criteria meant clinical guidelines published by the National Health and Family Planning Commission of the People's Republic of China, which were consistent with criteria published by the World Health Organization.); 6) the studies were published from Jan 1, 2000 to Dec 31, 2016.

The exclusion criteria were as follows: 1) studies that had improper age divisions (the difference between the upper age and the lower age is more than 40 in any age group); 2) studies that surveyed hospitalized patients rather than the ambulatory population; 3) studies that were not carried out in mainland China; 4) reviews and editor reports.

\section{Data extraction}

According to the inclusion and exclusion criteria, Thermite MARA, Longteng Ma, and Shuo Wang read all the articles and extracted the following data independently: title, author, the number of target populations and patients, age groups, study area, and career status (in-service or retired). We mapped the included populations to the 5 theater commands (Central, Western, Eastern, Northern, and Southern Theater Commands). Fan Yang reviewed every disagreement. Few studies provide data about the complications of chronic diseases, so we did not analyze the prevalence rates of complications in chronic diseases. The study selection process and reasons for exclusions are depicted in Fig. 1.

\section{Statistical analysis}

STATA 14.0 StataCorp LLC, College Station, TX, USA) and R 3.3.2 with the "meta" package were utilized for data analyses. For each disease, the prevalence rates from the different studies were combined and the $95 \%$ confidence interval $(95 \% \mathrm{CI})$ was calculated. Then, homogeneity tests were carried out $\left(I^{2}>50 \%\right.$ was chosen as the threshold of significant heterogeneity). When heterogeneity existed, a random effects model was selected to pool the prevalence data from the different studies. Subgroup analyses were performed to compare the prevalence rates of the chronic diseases among officers in different age groups $(30-59,60-79,>80$ years old), and in different theater commands. A Q-test based on the analysis of variance was performed in the subgroup analyses to determine whether the difference between the subgroups was significant or not. In 


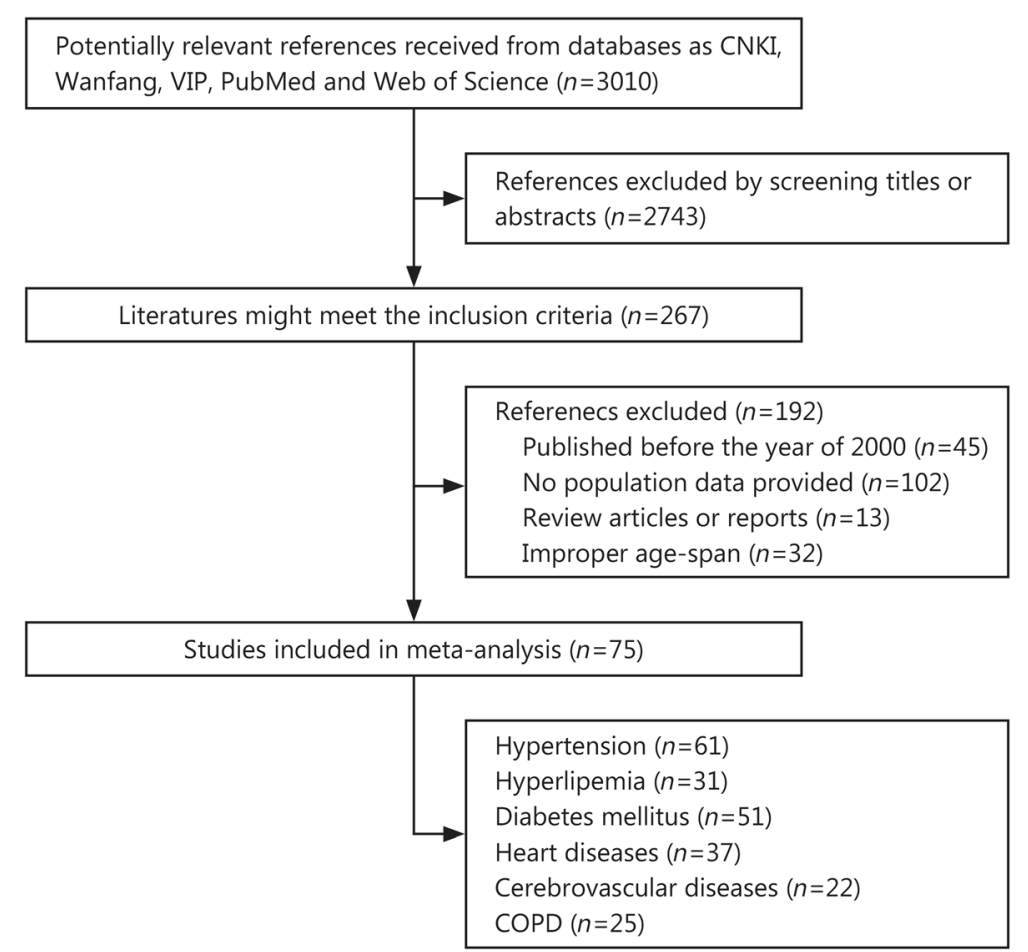

Fig. 1 The procedure for selecting studies. COPD. Chronic obstructive pulmonary disease

analyses that involved more than 10 studies, an Egger test was performed to test the publication bias, and $P<0.05$ was considered statistically significant.

\section{Results}

\section{Overall analysis}

A total of 75 studies were eventually included in this study (Table 1 and Appendix Table 2). Of those, 61 articles reported hypertension, 31 reported hyperlipidemia, 51 reported diabetes mellitus, 37 reported heart diseases, 22 reported cerebrovascular diseases, and 25 reported COPD. A total of 90,758 officers were surveyed in the 75 studies, and all of them were older than 30 years old. Among these military officers, 28,794 were diagnosed with hypertension, 11,936 were diagnosed with hyperlipidemia, 11,752 were diagnosed with diabetes, 14,644 were diagnosed with heart diseases, 2064 were diagnosed with cerebrovascular diseases, and 3670 were

Table 1 Overall analysis of six chronic diseases

\begin{tabular}{|c|c|c|c|c|c|c|}
\hline Disease & Number of studies & Included References & $\begin{array}{l}\text { In-service/ } \\
\text { Retired/Both }\end{array}$ & Prevalence Rate & $P^{2}$ & $\begin{array}{l}\text { P value of } \\
\text { Egger Test }\end{array}$ \\
\hline Hypertension & 61 & [12-72] & $9 / 46 / 6$ & $46.65 \%$ (41.83\%-51.52\%) & $99.27 \%$ & 0.11 \\
\hline Hyperlipidemia & 31 & $\begin{array}{l}{[14,16,18,19,21,26,27,30-32,34,36-39,} \\
42-44,46-49,58,62-65,67,70-73]\end{array}$ & $4 / 23 / 4$ & $30.86 \%(26.41 \%-35.7 \%)$ & $98.89 \%$ & 0.67 \\
\hline $\begin{array}{l}\text { Diabetes } \\
\text { mellitus }\end{array}$ & 51 & $\begin{array}{l}{[14,15,18,19,20,21,22,24-31,33,34,36-46,} \\
48-51,53,54,57,59,63-68,70-72,74-79]\end{array}$ & $4 / 43 / 4$ & $20.73 \%$ (16.47\%-25.75\%) & $99.39 \%$ & 0.88 \\
\hline Heart diseases & 37 & $\begin{array}{l}{[14,18-22,25-29,33,34,36,38,39,40-46,} \\
48,49,50-54,59,62,64,67,70,71,72]\end{array}$ & $2 / 30 / 5$ & $48.26 \%(41.7 \%-54.89 \%)$ & $99.25 \%$ & 0.01 \\
\hline $\begin{array}{l}\text { Cerebrovascular } \\
\text { disease }\end{array}$ & 22 & $\begin{array}{l}{[15,20,21,27-29,33,34,43,48,50,52,54,} \\
59,71,80-86]\end{array}$ & $1 / 21 / 0$ & $20.16 \%(14.75 \%-26.94 \%)$ & $99.02 \%$ & 0.93 \\
\hline COPD & 25 & $\begin{array}{l}{[16,18,21,25,27,28,29,30,33,34,39,40,} \\
41,44-46,48,50,51,53,54,66,67,70,71]\end{array}$ & $0 / 23 / 2$ & $16.60 \%(12.95 \%-21.03)$ & $98.28 \%$ & 0.39 \\
\hline
\end{tabular}


diagnosed with COPD. As shown in Table 1, the overall prevalence rate of hypertension, hyperlipidemia, diabetes mellitus, heart diseases, cerebrovascular diseases, and COPD was 46.65\% (95\% CI $41.83-51.52 \%), \quad 30.86 \% \quad(26.41-35.70 \%), \quad 20.7 \%$ (16.47-25.75\%), $\quad 48.26 \% \quad(41.70-54.89 \%), \quad 20.16 \%$ (14.75-26.94\%), and $16.60 \%$ (12.95-21.03\%), respectively. As heterogeneity existed, the data were pooled using a random effect model.

\section{The prevalence rates of chronic diseases among the subgroups \\ The prevalence rates of chronic diseases among the different age groups}

To increase the comparability, we set 3 age groups with sufficient participants in each group: 3059 years (13,415 participants), 60-79 years $(32,873$ participants) and older than 80 years (11,998 participants). Meta-analyses on age-subgroups were conducted to reduce the effect of age structure on the prevalence. A general increasing trend for the prevalence was shown in the forest plots for most of the diseases (Fig. 2). The prevalence rates of hypertension $(P<0.001)$, diabetes $(P<0.001)$, heart diseases $(P<0.001)$, cerebrovascular diseases $(P=0.005)$, and COPD $(P=0.028)$ differed significantly between age groups. However, this phenomenon was not found in the prevalence rate of hyperlipidemia $(P=0.457$, Fig. 3). Thus, the prevalence rates of chronic diseases increased rapidly with age except for hyperlipidemia.

\section{The prevalence rates of chronic diseases between retired officers and in-service officers}

Among the 75 articles included, 62 reported data from retired officers and 19 reported data from inservice officers. The prevalence rates of heart diseases, hypertension, cerebrovascular diseases, and diabetes mellitus in retired officers were significantly higher than those in in-service officers. The prevalence rate of heart disease in retired officers was 54.7 percentage points higher than in-service officers (in-service officers vs. retired officers: $1.9 \%$ vs. $56.6 \%)$. The numbers were 32.9 for hypertension (in-service officers vs. retired officers: $20.9 \%$ vs. $53.8 \%$ ), 22.5 for cerebrovascular diseases (in-service officers vs. retired officers: $0.6 \%$ vs. $23.1 \%$ ), and 19.7 for diabetes (in-service officers vs. retired officers: $5.3 \%$ vs. $25.0 \%)$. No significant differences in the prevalence of hyperlipidemia were found between retired officers and those in service (in-service officers vs. retired officers $=25.1 \%$ vs. $32.6 \%$, Fig. 4). We did not find any article reporting the prevalence rate of COPD among in-service officers. The numbers of studies concerning hypertension, hyperlipidemia, diabetes mellitus, heart diseases, cerebrovascular disease, and COPD for in-service military officers were $9,4,4,2,1$, and 0 , respectively. The number of studies among active officers was not sufficient to perform an Egger test.

\section{The prevalence rates of chronic diseases among the 5 theater commands}

We analyzed the cities where the articles were carried out and matched these cities to the 5 theater commands. A total of 12 articles were from the Eastern Theater Command, 30 articles from Central Theater Command, 7 articles from Northern Theater Command, 8 articles from Southern Theater Command, and 18 articles from Western Theater Command. Significant differences between the theater commands were observed for the prevalence rate of cerebrovascular disease $(P<0.001$, Fig. 5).

\section{Publication bias}

Publication bias was a type of bias that occurred when the research outcome influenced the decision whether to publish the study. We made funnel plots and performed Egger tests to explore the publication bias. No significant result was observed except for heart disease. Inspection of the funnel plot showed significant bias with a positive skew for the prevalence rate of heart disease, which indicated that the result of heart diseases should be carefully interpreted (Table 1).

\section{Discussion}

Our study summarized the prevalence rates of six chronic diseases among Chinese military officers older than 30 years old. We found that the prevalence rates of chronic disease increased with age, except for the prevalence rate of hyperlipidemia. We also found that cerebrovascular disease was more frequent in Northern Theater Command.

Figure 3 shows that the prevalence rates of chronic diseases differ significantly among age groups. Increasing trends were pronounced in COPD, heart diseases, diabetes, and cerebrovascular diseases. Interestingly, the prevalence of hyperlipidemia did not differ significantly among the different age groups, possibly because hyperlipidemia may be caused by food structure or physical activity or both [5]. Previous studies have demonstrated that hyperlipidemia is correlated with hypertension, heart disease, and diabetes mellitus $[4,6]$.

The prevalence rates of chronic disease were higher in retired military officers than those in active military officers. Age structure might be the major cause of this difference. Here, we demonstrated that 
$\mathbf{a}_{\underline{\mathrm{D}}}^{\mathrm{Stu}}$

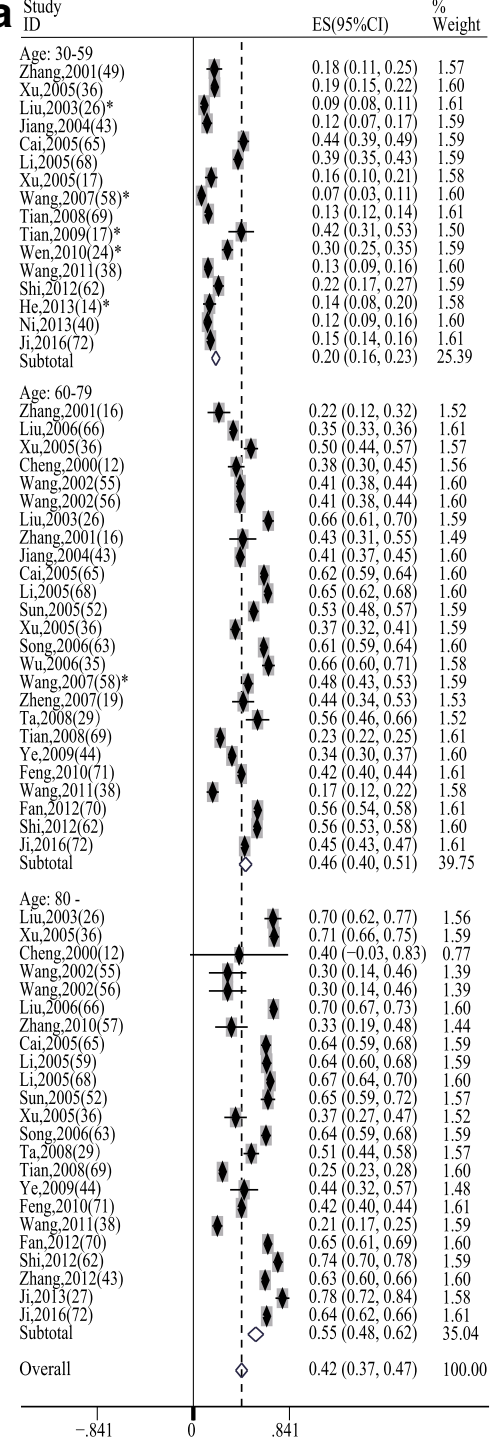

C Study

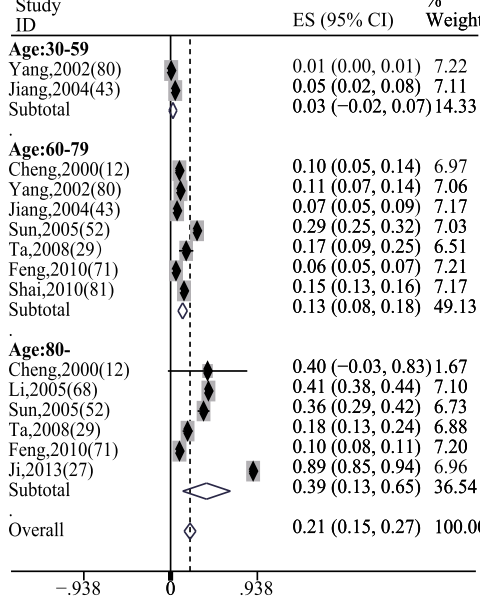

b $\frac{\text { Study }}{\mathrm{ID}}$

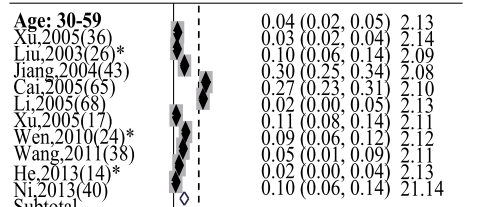

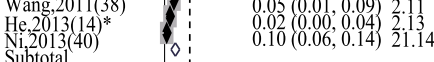
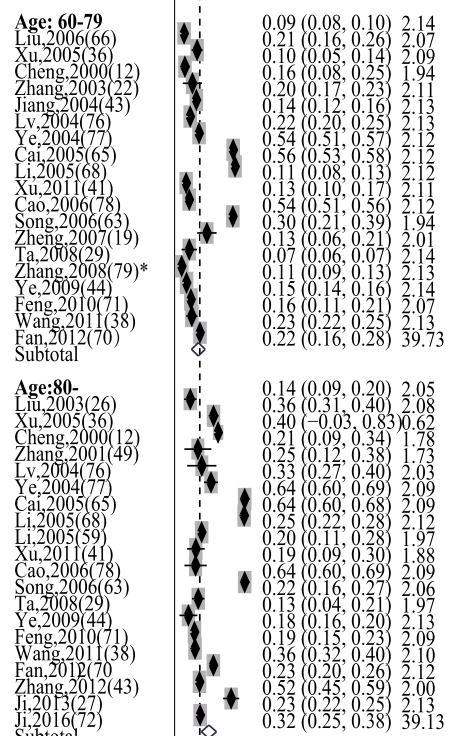

\begin{tabular}{l|lll}
$\begin{array}{l}\text { Subtotal } \\
\text { Overall }\end{array}$ & $\wp$ & $0.23(0.19,0.27)$ & 100.00 \\
\hline-829 & 1 & & \\
\hline
\end{tabular}

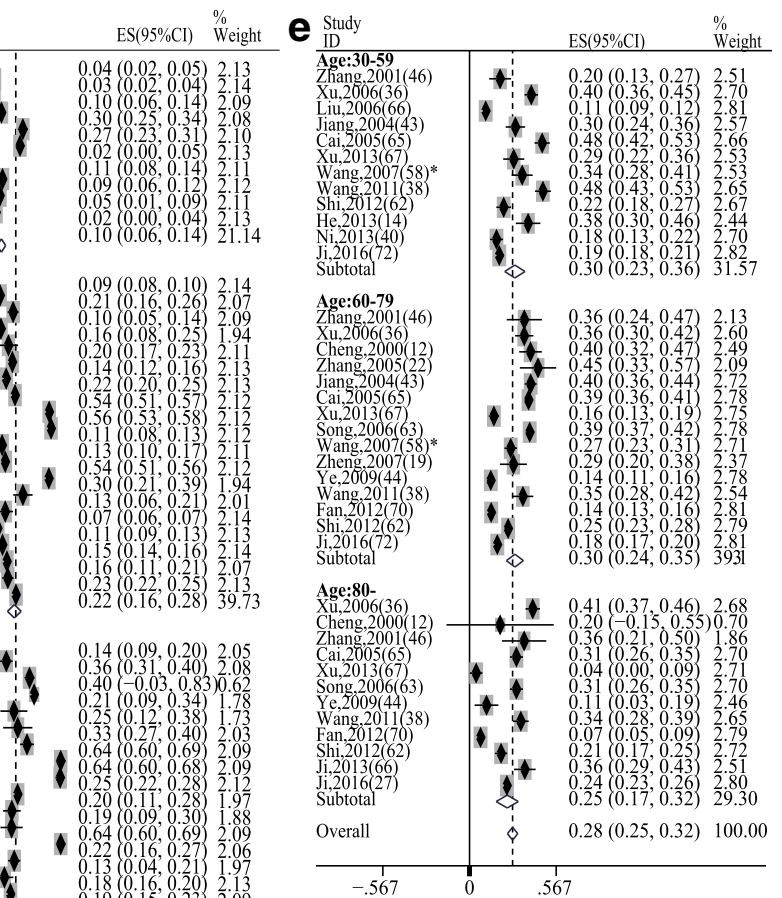

$\mathbf{d}_{\mathrm{ID}}^{\text {Study }}$

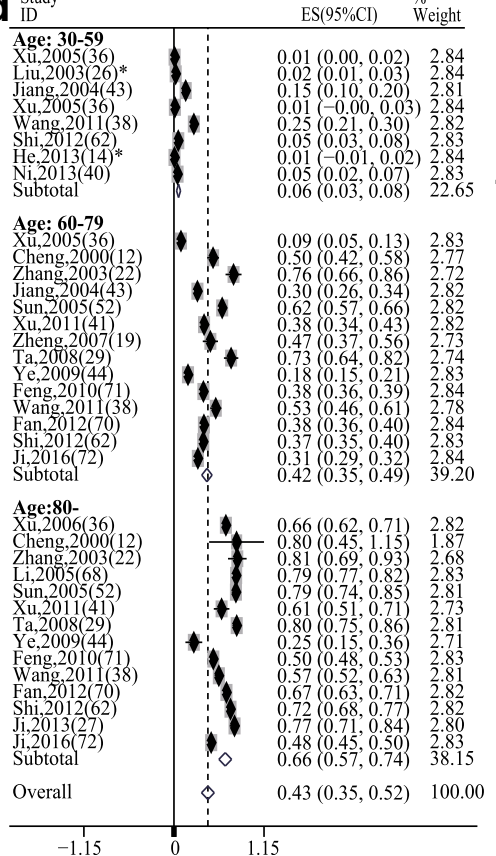

$\mathbf{f} \mathrm{Sth}$

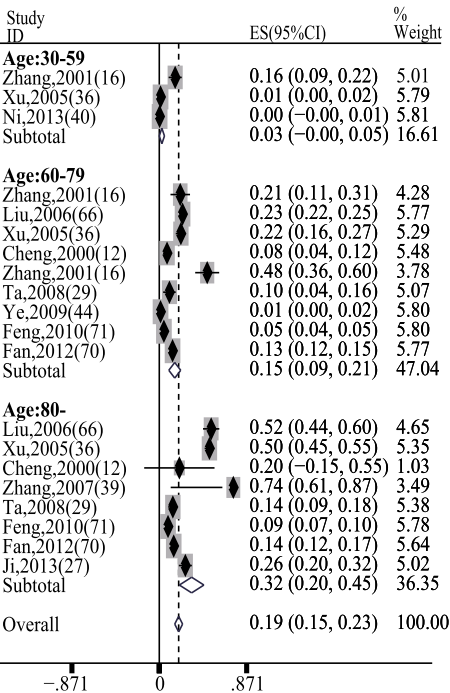

Fig. 2 Meta-analysis on the prevalence of the major chronic diseases by age group. a. Hypertension; b. Diabetes mellitus; c. Cerebrovascular diseases; $\mathbf{d}$. Heart diseases; e. Hyperlipidemia; $\mathbf{f}$. Chronic obstructive pulmonary disease. ${ }^{*}$ study was carried out in active military officers 


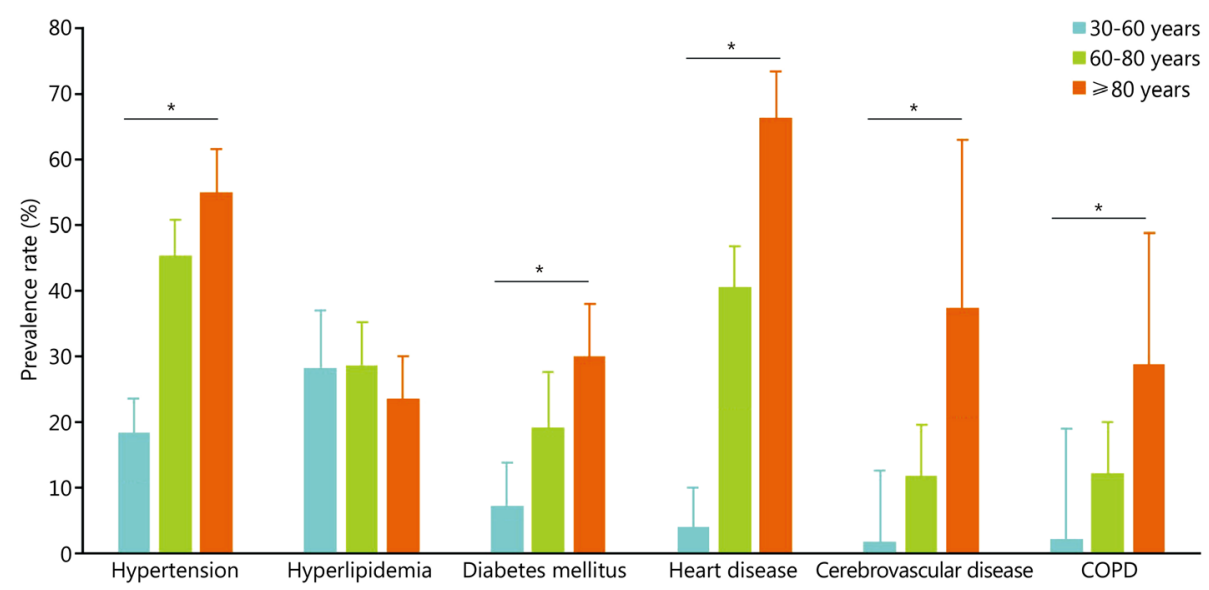

Fig. 3 The prevalence rates of the major chronic diseases of military officers in different age groups. Bars indicate the $95 \%$ confidence intervals (Cl) in this plot. * $P<0.05$. COPD. Chronic obstructive pulmonary disease

evident increases were observed in heart diseases and hypertension in retired officers. Lifestyle changes after retirement might contribute to this increase. Thus, more attention should be paid to heart disease and hypertension prevention after retirement.

The prevalence of chronic disease, except cerebrovascular diseases, was not different among the 5 Theater Commands. This suggested that the major risk factors for these chronic diseases were not different in the 5 theater commands. However, the prevalence rate of cerebrovascular diseases was much higher in the Northern Theater Command, which might be illustrated by the high-salt diet and cold climate in Northern China. High salt intake has been shown to be associated with blood pressure and stroke [7]. The highly variable climate in Northern China might also contribute to the higher prevalence of cerebrovascular diseases. Large population-based studies showed that the changeable climate was a risk factor for cerebrovascular diseases [8]. Although the risk factors for the chronic diseases were not different in the 5 theater commands, the risk factors promoting the development of cerebrovascular diseases, such as high salt intake and cold climate, are specific in the Northern Theater Command.

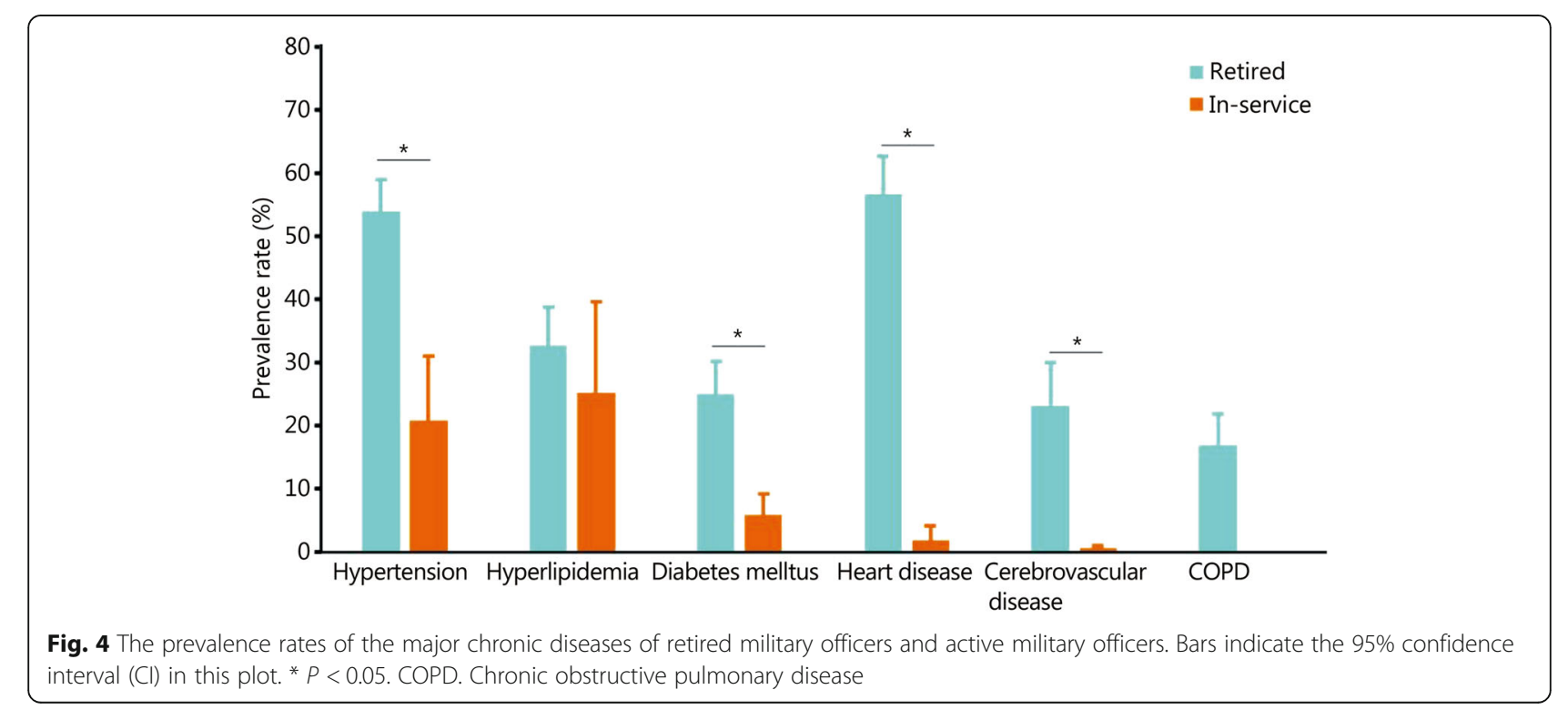




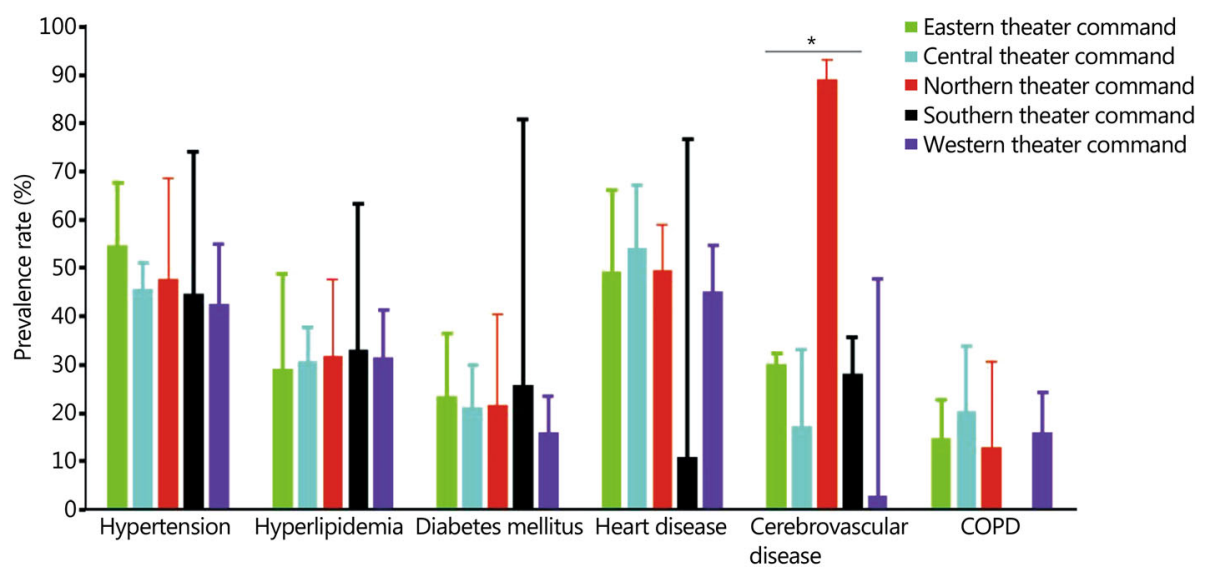

Fig. 5 The prevalence rates of the major chronic diseases of military officers in 5 different theater commands. Bar indicates $95 \%$ confidence interval (Cl) in this plot. ${ }^{*} P<0.05$. COPD. Chronic obstructive pulmonary disease

The prevalence rates of hypertension, diabetes mellitus, and COPD in this study are close to the corresponding data at the national level [2-4]. Of note, the estimated hypertension prevalence in the natural population in China was $47 \%$ in the $65-74$ age group, while it was $46 \%$ in military officers in the $60-80$ age group [9]. In terms of diabetes, the estimated prevalence was $23 \%$ in the $60-69$ age group, while the number was $22 \%$ in military officers [4]. The same was true for COPD (civilian vs. military officers $=12 \%$ vs. $15 \%$, in 60-69 age group) [10]. However, the prevalence rate of hyperlipidemia in our study is lower than that in a nationwide meta-analysis (civilian vs. military officers $=41.9 \%$ vs. $30.9 \%$ ) [11]. As shown in our study, the prevalence of hyperlipidemia did not increase with age. For military officers, physical training in their youth might reduce the risk of hyperlipidemia. To date, no cerebrovascular prevalence rate has been reported nationwide.

There are many centers for disease control and prevention and military hospitals in the Chinese military system, which provides free medical service to both active and retired military officers. However, it seems that these authorities do not significantly reduce the prevalence rates of chronic disease in Chinese military officers. Our study indicates that the primary prevention of major chronic diseases in Chinese military system should be improved. Intervention on the unhealthy lifestyle of military officers is necessary for the early prevention of chronic diseases. In addition, it is necessary to promote a low-salt diet in Northern China. These recommendations are suitable for both active military officers and retired military officers and should be realized by the corresponding healthcare providers.

\section{Limitation and strength}

Our study has several limitations. First, there was heterogeneity between the different studies. Second, as the age structure of the study population was different from that of active military officers, the overall prevalence rates must be interpreted with caution. Third, publication bias existed in the heart disease studies. Although our study has advantages, to the best of our knowledge, this is the first study investigating the prevalence rates and age-specific prevalence rates of major chronic diseases among Chinese military officers on a whole-military scale. We also conducted sub-group analyses to evaluate the prevalence rates among age-groups, career status, and theater commands. An overview of disease burden among the military officers was important for optimizing military medical service.

\section{Conclusion}

Our study provides a comprehensive overview and provides the prevalence rates of chronic diseases in Chinese military officers older than 30 years old. The prevalence rates of chronic disease among Chinese military officers were consistent with those among civilians, except for hyperlipidemia. The prevalence of hypertension, diabetes, heart diseases, cerebrovascular diseases, and COPD increased with increasing age, whereas this increasing trend was not shown in hyperlipidemia. The prevalence of cerebrovascular diseases was extremely high in the Northern Theater Command, which might be attributed to diet and highly variable climate. Overall, this research might help optimize the prevention and control of chronic diseases in military systems worldwide. 


\section{Appendix}

Table $\mathbf{2}$ Characteristics of included studies

\begin{tabular}{|c|c|c|c|c|c|c|c|c|c|c|c|}
\hline Status & $\begin{array}{l}\text { Theater } \\
\text { command }\end{array}$ & Author & Year & $\begin{array}{l}\text { Age } \\
\text { groups }\end{array}$ & Population & Hypertension & Hyperlipidemia & $\begin{array}{l}\text { Diabetes } \\
\text { mellitus }\end{array}$ & $\begin{array}{l}\text { Heart } \\
\text { diseases }\end{array}$ & $\begin{array}{l}\text { Cerebrovascular } \\
\text { diseases }\end{array}$ & COPD \\
\hline in-service & central & Cheng et al. [12] & 2000 & - & 54 & 10 & - & - & - & - & - \\
\hline in-service & central & Wu et al. [13] & 2011 & - & 124 & 11 & - & - & - & - & - \\
\hline in-service & central & He et al. [14] & 2013 & 1 & 137 & 20 & 54 & 7 & 1 & - & - \\
\hline retired & southern & Pan et al. [15] & 2013 & - & 68 & 23 & - & 35 & - & 32 & - \\
\hline retired & western & Zhang et al. [16] & 2001 & 1,2 & 185 & 37 & 29 & - & - & - & 33 \\
\hline in-service & western & Tian et al. [17] & 2009 & 1 & 95 & 41 & - & - & - & - & - \\
\hline retired & central & Zan et al. [18] & 2003 & 2,3 & 106 & 43 & 45 & 20 & 84 & - & 62 \\
\hline retired & eastern & Zheng et al. [19] & 2007 & 2 & 98 & 44 & 29 & 30 & 46 & - & - \\
\hline retired & central & Zhao et al. [20] & 2011 & - & 89 & 46 & - & 24 & 55 & 30 & - \\
\hline retired & central & Chen et al. [21] & 2000 & 2,3 & 168 & 65 & 68 & 18 & 87 & 13 & 14 \\
\hline retired & central & Zhang et al. [22] & 2005 & - & 99 & 69 & - & 36 & 63 & - & - \\
\hline in-service & western & Xie et al. [23] & 2016 & - & 280 & 81 & - & - & - & - & - \\
\hline in-service & central & Wen et al. [24] & 2010 & 1 & 319 & 98 & - & 36 & - & - & - \\
\hline retired & western & Lv et al. [25] & 2008 & - & 149 & 105 & - & 50 & 100 & - & 31 \\
\hline in-service & southern & Liu et al. [26] & 2003 & 1 & 1304 & 126 & 142 & 42 & 30 & - & - \\
\hline retired & northern & Ji et al. [27] & 2013 & 3 & 172 & 138 & 64 & 92 & 135 & 111 & 45 \\
\hline retired & central & Wang et al. [28] & 2015 & - & 175 & 151 & - & 90 & 128 & 56 & 47 \\
\hline retired & central & Ta et al. [29] & 2008 & 2,3 & 288 & 155 & - & 57 & 228 & 37 & 36 \\
\hline retired & eastern & Jing et al. [30] & 2010 & - & 227 & 172 & 176 & 187 & - & - & 91 \\
\hline retired & central & Zhang et al. [31] & 2016 & - & 477 & 178 & 292 & 65 & - & - & - \\
\hline in-service & western & Ma et al. [32] & 2008 & - & 1053 & 184 & 353 & - & - & - & - \\
\hline retired & central & Fang et al. [33] & 2013 & - & 268 & 186 & - & 46 & 212 & 63 & 78 \\
\hline retired & central & Yang et al. [34] & 2013 & - & 267 & 190 & 107 & 95 & 199 & 113 & 62 \\
\hline retired & southern & Wu et al. [35] & 2006 & 2 & 282 & 194 & - & - & - & - & - \\
\hline retired & central & Xu et al. [36] & 2005 & $1,2,3$ & 690 & 226 & 124 & 70 & 229 & - & - \\
\hline retired & northern & Zhang et al. [37] & 2013 & - & 356 & 229 & 194 & 161 & - & - & - \\
\hline $\begin{array}{l}\text { in-service/ } \\
\text { retired }\end{array}$ & northern & Wang et al. [38] & 2011 & $1,2,3$ & 1516 & 234 & 685 & 178 & 569 & - & - \\
\hline retired & northern & Zhang et al. [39] & 2007 & - & 1094 & 236 & 138 & 125 & 412 & - & 50 \\
\hline $\begin{array}{l}\text { in-service/ } \\
\text { retired }\end{array}$ & eastern & $\mathrm{Ni}$ et al. [40] & 2013 & 1 & 811 & 240 & - & 48 & 127 & - & 46 \\
\hline retired & western & Xu et al. [41] & 2011 & - & 534 & 356 & - & 58 & 317 & - & 88 \\
\hline retired & southern & Huang et al. [42] & 2016 & - & 433 & 268 & 256 & 250 & 174 & - & - \\
\hline retired & central & Jiang et al. [43] & 2004 & 1,2 & 777 & 270 & 300 & 139 & 207 & 37 & - \\
\hline retired & eastern & Ye et al. [44] & 2009 & 2,3 & 760 & 271 & 107 & 87 & 143 & - & 9 \\
\hline retired & eastern & Wang et al. [45] & 2016 & - & 328 & 282 & - & 97 & 265 & - & 68 \\
\hline retired & central & Li et al. [46] & 2008 & - & 418 & 282 & 157 & 122 & 275 & - & 104 \\
\hline retired & eastern & Wu et al. [47] & 2003 & - & 1251 & 313 & 709 & - & - & - & - \\
\hline retired & western & Fei et al. [48] & 2002 & - & 2086 & 332 & 804 & 152 & 581 & 8 & 141 \\
\hline retired & western & Song et al. [49] & 2005 & - & 764 & 337 & 301 & 166 & 275 & - & - \\
\hline retired & eastern & Chen et al. [50] & 2013 & - & 478 & 348 & - & 108 & 239 & 101 & 70 \\
\hline retired & northern & Xu et al. [51] & 2011 & - & 534 & 356 & - & 58 & 317 & - & 88 \\
\hline
\end{tabular}


Table 2 Characteristics of included studies (Continued)

\begin{tabular}{|c|c|c|c|c|c|c|c|c|c|c|c|}
\hline Status & $\begin{array}{l}\text { Theater } \\
\text { command }\end{array}$ & Author & Year & $\begin{array}{l}\text { Age } \\
\text { groups }\end{array}$ & Population & Hypertension & Hyperlipidemia & $\begin{array}{l}\text { Diabetes } \\
\text { mellitus }\end{array}$ & $\begin{array}{l}\text { Heart } \\
\text { diseases }\end{array}$ & $\begin{array}{l}\text { Cerebrovascular } \\
\text { diseases }\end{array}$ & COPD \\
\hline retired & eastern & Sun et al. [52] & 2005 & 2,3 & 716 & 416 & - & - & 485 & 159 & - \\
\hline retired & western & Song et al. [53] & 2005 & - & 534 & 423 & - & 58 & 317 & - & 88 \\
\hline retired & eastern & Sun $X$ et al. [54] & 2011 & - & 745 & 427 & - & 118 & 494 & 161 & 235 \\
\hline retired & central & Wang et al. [55] & 2002 & 2,3 & 1174 & 490 & - & - & - & - & - \\
\hline retired & central & Wang et al. [56] & 2002 & 2,3 & 880 & 307 & - & - & - & - & - \\
\hline retired & western & Zhang et al. [57] & 2010 & 3 & 933 & 603 & - & 219 & - & - & - \\
\hline in-service & central & Wang et al. [58] & 2007 & 1,2 & 1598 & 635 & 250 & - & - & - & - \\
\hline retired & central & Li et al. [59] & 2005 & 3 & 974 & 673 & - & 248 & 784 & 288 & - \\
\hline retired & western & Zhou et al. [60] & 2008 & - & 1399 & 740 & - & - & - & - & - \\
\hline retired & southern & Xie et al. [61] & 2011 & 2,3 & 1240 & 878 & - & - & - & - & - \\
\hline $\begin{array}{l}\text { in-service/ } \\
\text { retired }\end{array}$ & northern & Shi et al. [62] & 2012 & $1,2,3$ & 1891 & 1060 & 464 & - & 766 & - & - \\
\hline retired & central & Song et al. [63] & 2006 & 2,3 & 1687 & 1077 & 643 & 975 & - & - & - \\
\hline retired & eastern & Cha et al. [64] & 2012 & - & 1244 & 1080 & 208 & 396 & 769 & - & - \\
\hline retired & central & Cai et al. [65] & 2005 & $1,2,3$ & 2021 & 1225 & 900 & 1072 & - & - & - \\
\hline retired & eastern & Liu et al. [66] & 2006 & 2,3 & 2862 & 1250 & - & 309 & - & - & 828 \\
\hline $\begin{array}{l}\text { in-service/ } \\
\text { retired }\end{array}$ & western & Xu et al. [67] & 2013 & $1,2,3$ & 2457 & 1284 & 1151 & 531 & 759 & - & 718 \\
\hline retired & central & Li et al. [68] & 2005 & $1,2,3$ & 2172 & 1325 & - & 1141 & - & - & - \\
\hline $\begin{array}{l}\text { in-service/ } \\
\text { retired }\end{array}$ & western & Tian et al. [69] & 2008 & $1,2,3$ & 6002 & 1397 & - & - & - & - & - \\
\hline retired & western & Fan et al. [70] & 2012 & 2,3 & 2668 & 1595 & 348 & 710 & 1201 & - & 364 \\
\hline retired & central & Feng et al. [71] & 2010 & 2,3 & 3889 & 1890 & - & 730 & 1887 & 231 & 274 \\
\hline $\begin{array}{l}\text { in-service/ } \\
\text { retired }\end{array}$ & central & Ji et al. [72] & 2016 & $1,2,3$ & 7788 & 3072 & 1925 & 490 & 1684 & - & - \\
\hline retired & southern & Ze et al. [73] & 2003 & - & 2047 & - & 913 & - & - & - & - \\
\hline retired & eastern & Zheng et al. [74] & 2012 & - & 705 & - & - & 290 & - & - & - \\
\hline retired & central & Fan et al. [75] & 2003 & - & 1776 & - & - & 323 & - & - & - \\
\hline retired & central & Lv et al. [76] & 2004 & 2,3 & 1217 & - & - & 183 & - & - & - \\
\hline retired & western & Ye et al. [77] & 2004 & 2,3 & 1630 & - & - & 398 & - & - & - \\
\hline retired & western & Cao et al. [78] & 2006 & 2,3 & 395 & - & - & 58 & - & - & - \\
\hline in-service & western & Zhang et al. [79] & 2008 & 2 & 10207 & - & - & 754 & - & - & - \\
\hline retired & central & Yang et al. [80] & 2002 & 1,2 & 325 & - & - & - & - & 28 & - \\
\hline in-service & central & Shai et al. [81] & 2002 & - & 3105 & - & - & - & - & 16 & - \\
\hline retired & central & Zhou et al. [82] & 2008 & - & 1245 & - & - & - & - & 43 & - \\
\hline retired & southern & Duan et al. [83] & 2012 & - & 1024 & - & - & - & - & 150 & - \\
\hline retired & southern & He et al. [84] & 2013 & - & 1498 & - & - & - & - & 220 & - \\
\hline retired & western & Sai et al. [85] & 2010 & 2 & 1232 & - & - & - & - & 129 & - \\
\hline retired & central & Wu et al. [86] & 2014 & - & 164 & - & - & - & - & 38 & - \\
\hline
\end{tabular}

Age groups : 1="30-59 years group", 2="60-79 years group", 3="80- years group". "-": data not available 


\section{Abbreviations}

COPD: Chronic obstructive pulmonary disease; CNKI: China National Knowledge Infrastructure; VIP: VIP Database for Chinese Technical Periodicals

\section{Acknowledgements}

Not applicable.

\section{Funding}

This study was supported by the Key Research Fund from Chinese Military Research Project (AWS16J023).

\section{Availability of data and materials}

The datasets used and/or analyzed during the current study are available from the corresponding author on reasonable request.

\section{Authors' contributions}

TM, LTM, SW searched databases and downloaded related articles. TM, LTM SW read all articles and extracted data separately. FY reviewed every disagreement. TM, LTM, SW performed all analyses separately. TM, LTM, SW and GWC were the major contributor in writing the manuscript. LW, FY, JHS, JHY and YCC revised the manuscript. All authors read and approved the final manuscript.

\section{Ethics approval and consent to participate}

Not applicable.

\section{Consent for publication}

Not applicable.

\section{Competing interests}

The authors declare that they have no competing interests.

Received: 23 May 2017 Accepted: 7 December 2017

Published online: 30 January 2018

\section{References}

1. Zhou M, Wang H, Zhu J, Chen W, Wang L, Liu S, et al. Cause-specific mortality for 240 causes in China during 1990-2013: a systematic subnational analysis for the global burden of disease study 2013. Lancet. 2016:387:251-72

2. Gao Y, Chen G, Tian H, Lin L, Lu J, Weng J, et al. Prevalence of hypertension in China: a cross-sectional study. PLoS One. 2013;8(6):e65938.

3. Yang L, Shao J, Bian Y, Wu H, Shi L, Zeng L, et al. Prevalence of type 2 diabetes mellitus among inland residents in China (2000-2014): a meta-analysis. J Diabetes Investig. 2016;7(6):845-52

4. Zhong N, Wang C, Yao W, Chen P, Kang J, Huang S, et al. Prevalence of chronic obstructive pulmonary disease in China: a large, population-based survey. Am J Respir Crit Care Med. 2007;176(8):753-60.

5. Patel V, Joharapurkar A, Kshirsagar S, Patel HM, Pandey D, Patel D, et al. Central and peripheral glucagon reduces hyperlipidemia in rats and hamsters. Drug Res (Stuttg). 2017;67(6):318-26.

6. Havel RJ, Rapaport E. Management of primary hyperlipidemia. N Engl J Med. 1995:332(22):1491.

7. Perry IJ. Dietary salt intake and cerebrovascular damage. Nutr Metab Cardiovasc Dis. 2000;10(10):229-35.

8. Wang XY, Barnett AG, Hu W, Tong S. Temperature variation and emergency hospital admissions for stroke in Brisbane, Australia, 1996-2005. Int J Biometeorol. 2009;53(6):535-41

9. Gu D, Reynolds K, Wu X, Chen J, Duan X, Muntner P, et al. Prevalence, awareness, treatment, and control of hypertension in China. Hypertension. 2002:40(6):920-7.

10. Xu Y, Wang L, He J, Bi Y, Li M, Wang T, et al. Prevalence and control of diabetes in Chinese adults. JAMA. 2013;310(9):948-59.

11. Huang Y, Gao L, Xie X, Tan SC. Epidemiology of dyslipidemia in Chinese adults: meta-analysis of prevalence, awareness, treatment, and control. Popul Health Metr. 2014:12(1):28.

12. Cheng $L$, Zhang $W$, Zhao C, Chen Y, Yang $C$. The occurrence of youth hypertension in army troop and the relative factors. Chin J Hypertens. 2000;1:69-71. [in Chinese]

13. Wu Q, Liu P. An analysis on the medical examination of 128 military officer in research institution. Chin J Convalescent Med. 2011;20:185-6. [in Chinese]
14. $\mathrm{He} \mathrm{H}$. The prevalence of chronic disease in 141 military officers. Chin $J$ Convalescent Med. 2013;22:1135-6. [in Chinese]

15. Pan J. Prevalence study on chronic diseases among retired officers in army. Healthy Required. 2013;12:49. [in Chinese]

16. Zhang J. Survey and follow-up of health status of 201 retired officers in army. Med J Chin Peoples Health. 2001;25:130-3. [in Chinese]

17. Tian X. Prevalence of hypertension in a military academy. Chongqing Med. 2009:38:479-80. [in Chinese]

18. Zhan J, Yang Z, Liu Y. Investigation on the prevalence of chronic diseases among 109 retired officers. Prev Med Trib. 2003;9:521-2. [in Chinese]

19. Zheng Z, Tao Y, Li G. A survey of the disease spectrum on retired officers in nursing hospital. J Navy Med. 2007;28:142-3. [in Chinese]

20. Zhao J, He J. Analysis of life quality of retired veteran officers and influencing factors in Tai'an. Chin J Health Care Med. 2011;13:39-41. [in Chinese]

21. Chen S. Investigation and analysis on the health status of 173 navy retired officers. J Pre Med Chin PLA. 2000:18:202-3. [in Chinese]

22. Zhang R. Clinical analysis of 102 cases of retired veteran officers. Chin J Clin Pract Med. 2005:8:107-9. [in Chinese]

23. Xie S, Chen H, Lin H, Li Z, Shi K, Chen J, et al. Analysis on health examination of 836 officers in military academies. J Prev Med Chin PLA. 2016;34:730-1. [in Chinese]

24. Wen $Y$, Shun $L$. An analysis on the medical examination of 328 military officers. Peoples Mil Surg. 2010;8:561. [in Chinese]

25. LV X, Li Z, Wang Y. Analysis on the rank of prevalence among retired army officers. Chin Med Her. 2008;5:114-5. [in Chinese]

26. Liu L, Yue L, Zhong Z, Zhu H. Investigation and countermeasure on the health status of in-service army officers. Chin J Health Care Med. 2003;5: 103-4. [in Chinese]

27. Ji $X$, Yun T, Wang $X$. Prevalence study in 235 retired officers in the army. Navy Med. 2013;34:257-8. [in Chinese]

28. Wang S, Zhu B, Wu D, Zhang Q. Investigation and analysis of medical examination results among military retired officers for more than three years. Chin J Health Care Med. 2015;17:132-3. [in Chinese]

29. Ta N, Sun C, Jiang Y, Shi Q, Zhao X. Prevalence research on retied officers over 70 years old of army. Chin J Geriatr. 2008:51:123-7. [in Chinese]

30. Jing $L$, Jia HD. Investigation and analysis on medical needs of healthy subjects of retired cadres in the army. Chin Hosp. 2010;14:25-7. [in Chinese]

31. Zhang J, Jiang S, Liu Q. Analysis of Health Examination Results of Retired Veteran Cadres in a Military Hospital. Peoples Mil Surg. 2016:17:1135. [in Chinese]

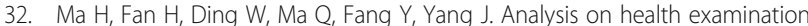
results of middle-aged and aged officers in desert district. Chin J Clin Healthc. 2008;11:526-7. [in Chinese]

33. Fang Y, Li G. Investigation on the prevalence of non-communicable diseases, NCDs in 276 military retired officers from Jinan. J Community Med. 2013:11:9-11. [in Chinese]

34. Yang X, Guo T, Song S. Investigation on health status of 275 retied officers in the army. Peoples Mil Surg. 2013;8:908. [in Chinese]

35. Wu S, Qi R. Epidemiologic study of hypertension in elderly veterans. Clin Med Off. 2006:34:206-8. [in Chinese]

36. $\mathrm{Xu}$ J, Shen W, Li Y. Analysis on the prevalence of 355 retirees in different age groups. J Prev Med Chin PLA. 2005:23:358-9. [in Chinese]

37. Zhang $H$, Yang $Y$, Gao $Y$, Wang $Y$. Investigation on the prevalence of metabolic syndrome in the elderly in Dalian officers rest department. Chin J Convalescent Med. 2013;22:688-90. [in Chinese]

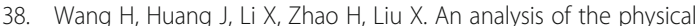
examination among army officers in Shenyang in 2011. Chin J Health Stat 2011;28:709. [in Chinese]

39. Zhang Y, Xu Y, Guan Y. Investigation on the common diseases of 1126 cases of senile convalescence. Clin J Med Off. 2007;35:377. [in Chinese]

40. $\mathrm{Ni} \mathrm{H}$, Yin Z, Li X, Wang G, Hu L. Analysis on the physical examination of 874 military officers. Mil Med J Southeast China. 2013;15:246-8. [in Chinese]

41. Xu D, Yang D, Zhang Y, Wang Y, Wang C, Lu O, Yi R. Characteristics of chronic diseases among retired veteran officers in Gansu province. Chin J Health Care Med. 2011:13:325-7. [in Chinese]

42. Huang H, Liu S. Analysis of the incidence rate of major chronic diseases in physical examination of military retired officers. Chin Foreign Med Res. 2016;14:148-9. [in Chinese]

43. Jiang X, Guo S. Evaluation of health status and health care strategies among retired veteran officers. Chin J Convalescent Med. 2004;13:31-2. [in Chinese] 
44. Ye F, Wu Y. Prevalence and drug-using among retied officers in army. Peoples Mil Surg. 2009;3:422-3. [in Chinese]

45. Wang N, Xie X, Gao M. Prevalence and drug-using of chronic disease among retied officers in army. Peoples Mil Surg. 2016;8:804-5. [in Chinese]

46. Li J, Sai X, He Y, Qin Y. An epidemiological survey of the diseases corporation and hypertension risk factors in retired military veterans in Beijing. Chin J Health Care Med. 2008;10:96-8. [in Chinese]

47. Wu Y, Lu X, Fei J, Zhang C, Zheng W, Huang B. Investigation on prevalence of diabetes mellitus complicated with hypertension among aged people in army. Clin J Med Off. 2003;31:79-81. [in Chinese]

48. Fei J, Wang H, Liu L, Wang H. Investigation and analysis on physical examination of military officers in Xi'an area for 5 years. Chin $J$ Health Care Med. 2002;4:171-2. [in Chinese]

49. Song F, Qiao R, Yang F. Research on the health status of retired army officers. J Fourth Mil Med Univ. 2005;26:2229. [in Chinese]

50. Chen F, Zhou L, Lu B, Zhang K. Investigation on the relationship between traditional Chinese medicine physique and chronic diseases in the retried officers of Nanjing. Jiangsu J Prev Med. 2013;24:23-5. [in Chinese]

51. Xu D, Yang D, Zhang Y, Wang C, Lu Q, Yi R. A survey on prevalence of chronic diseases among the retired officers in army of Lanzhou. Mod Pre Med. 2011;38:1660-3. [in Chinese]

52. Sun $X$, Wang $Q$, Huang F, Lu Y, Li Y, Wen H. Analysis on behavioral risk factors and incidence of the heart and cerebrovascular disease in 767 veterans. J Health Care Med Chin PLA. 2005;7:93-6. [in Chinese]

53. Song F, Qiao R, Yang F, Yang Y. Analysis on the health status of retired veteran officers in Lanzhou. J Chin Med Res. 2005;12:123-4. [in Chinese]

54. Sun X, Wang Q, Huang F, Lu Y, Li Y, Wen H. Investigation of chronic diseases in retired army cadres. Chin J Clin Health. 2005;8:107-9. [in Chinese]

55. Wang F, Li B, Xin S. An research on hypertension among elderly people in Qingdao area. J Health Care Med. 2002;4:169-70. [in Chinese]

56. Wang F, Li B, Xin S, Fang F, Liu Y, Fan C. A survey of senile hypertension incidence in aged military officers in Qingdao area. J Navy Med. 2002;23: 339-41. [in Chinese]

57. Zhang S, Yu K, Yuan J, Li Y, Huang X, Shi J. A survey on the hypertension among the retired army officers in Chengdu. Med J Natl Defend Forces Southwest China. 2010;20:1274-6. [in Chinese]

58. Wang $Y$, Shao F, Huang M, Wang $X$. An analysis on the medical examination of 1645 military officers. Over 40 years old. J Prev Med Chin PLA. 2007;25: 435-6. [in Chinese]

59. Li Y, Hu Y, Zhou Y. Investigation of hypertension and its present situation of treatment in 1002 cases $\geq 80$ years old in rest home for army leading officers in Beijing. Chin J Geriatr. 2005;24:627-30. [in Chinese]

60. Zhou J, Huang X. Cross-sectional study on hypertension among 70 and elder years people in cadre rest of Chengdu. J Mil Surg Southwest China. 2008;10:39-40. [in Chinese]

61. Xie Z, Lin Z, Wang Y, Feng G, Qian Y, Wu Z, et al. The characteristics of hypertension in the very elderly veterans in Guangzhou. Chin J Hypertens. 2011;6:557-60. [in Chinese]

62. Shi $H$, Cheng $H$, Wang $Y$. Analysis on health examination among military cadre in three years. Chin J Health Care Med. 2012;14:42-4. [in Chinese]

63. Song $\mathrm{K}, \mathrm{Yu} \mathrm{H}, \mathrm{Li}$ T. Prevalence of metabolic syndrome in elderly male officers in Beijing. Chin J Arterioscler. 2006;14:254-7. [in Chinese]

64. Cha J, Cheng R, Chen J. Analysis on 640 cases of healthy physical examination of retired military officers. Peoples Mil Surg. 2012;6:406. [in Chinese]

65. Cai L, Li J, Tang L, Jia X, Kong Q, Song K. Investigation on the prevalence of metabolic syndrome in 2080 cases of aged population in the army. J Nurs Adm. 2005:5:8-10. [in Chinese]

66. Liu D, Lu K, Liu Y, Qiu X, Ge W. Study on prevalence and cause of deaths among retied officers in army. J Prev Med Chin PLA. 2006;7:124-6. [in Chinese]

67. Xu X, Peng $H$, Xiao X, He X, Xu T, Liang $G$, et al. Health examination results of military male middle age and senile officers from Chengdu city in 2006 and 2010. Med J Natl Defend Forces Southwest China. 2013;2:124-6. [in Chinese]

68. Li J, Cui L, Cai L, Tang L, Ren S, Song K. Epidemiology investigation and analysis on metabolic syndrome and related diseases in military middle-aged and senile group in Beijing. Chin Nurs Res. 2005;19:1998-2000. [in Chinese]

69. Tian H, Li D, Song W, Zhong Z, Shi S, Zhou L, et al. Epidemiology survey of hypertension among military officers in northwest China. Med J Natl Defend Forces Northwest China. 2008;29:42-4. [in Chinese]
70. Fan H, Yan X, Rong J, Shen GL, Li Y, Liu F. The analysis on chronic disease and death cause of retired officers in Chengdu from 2006-2009. Chongqing Med. 2012;41:160-2. [in Chinese]

71. Feng $Y$, LV Q, Wang Y, Xin S. Analysis of health status of 4502 retired officers of people 's liberation Army. Med J Chin PLA. 2010;35:104-6. [in Chinese]

72. Ji H, Dong W, Yang C, Zhang T. An analysis of the physical examination among 9014 military officers in 2013. Chin J Health Care Med. 2016;18:240-2. [in Chinese]

73. Ze L, Wang L, Dai B. Analysis of blood lipid status and related disease spectrum of retired officers in Guangzhou area. Chin J Health Care Med. 2003;5:166-8. [in Chinese]

74. Zheng W, Wu Y, Lu X, Fei J, Zhang Z. Epidemiological investigation and evaluation of military elderly population with diabetes in Hangzhou. Clin J Med Off. 2012:40:127-9. [in Chinese]

75. Fan $\mathrm{C}$, Tian $\mathrm{H}, \mathrm{Xu}$ X, Lu J. Prevalence and incidence of diabetes in the elderly in Beijing army. Chin J Geriatr. 2003;22:364-7. [in Chinese]

76. LV X, Zhang $X$, Zheng J. Investigation on diabetes mellitus in 1252 retired veterans in Beijing. J Clin Rehabil Tissue Eng Res. 2004;8:6772-3. [in Chinese]

77. Ye X, Wang P, Sun H, Wang W, Zhang Z. Analysis of prevalence rate and risk factors of diabetes mellitus in 1677 elderly veterans. J Clin Rehabil Tissue Eng Res. 2004;8:4942-3. [in Chinese]

78. Cao A, Ma Z, Cheng J. Research on diabetes mellitus among older officers in the army. Chin J Clin Pract Med. 2006;8:102-3. [in Chinese]

79. Zhang J, Fan C, Ye M, Deng Y. A 4-year survey on the prevalence of diabetes in southwest China. Xizang Med. 2008;1:4-5. [in Chinese]

80. Yang $\mathrm{X}, \mathrm{Ma}$ W, Wang $\mathrm{Q}$. Prevalence of stroke and associated diseases in military personnel. Chin J Clin Pract Med. 2002;6:103-6. [in Chinese]

81. Yang X, Ma W, Wang Q, Cui L, Chen Z, Xu B. The prevalence rate of cerebrovascular diseases and their risk factors in people over 35 in Armed Police Forces. Med J Chin PAPF. 2002;13:707-9.

82. Zhou S, Yin Q, Cao S. Surveillance on stroke among retried army officers in Beijing. Chin J Health Care Med. 2008;10:183-5. [in Chinese]

83. Duan J, Xu X. Investigation on the prevalence rates of stroke and risk factors for stroke in retired officers in Changsha city. Chin J Cardiovasc Rehabil Med. 2012;21:581-3.

84. He W. Investigation of prevalence and risk factors of stroke among old officers men in Xiang. Shanxi Med J. 2013:42:483-4. [in Chinese]

85. Shai X, Yan Y. A cohort study on the incidence and death of stroke among men in army. Chin J Prev Control Chronic Dis. 2010;18:4-7. [in Chinese]

86. $\mathrm{Wu} L$, Sun P. Effect of health education on the prevention of stroke in retired cadres. Chin J Prim Med Pham. 2014;21:1269-70. [in Chinese]

\section{Submit your next manuscript to BioMed Central and we will help you at every step:}

- We accept pre-submission inquiries

- Our selector tool helps you to find the most relevant journal

- We provide round the clock customer support

- Convenient online submission

- Thorough peer review

- Inclusion in PubMed and all major indexing services

- Maximum visibility for your research

Submit your manuscript at www.biomedcentral.com/submit 